\title{
Response of wheat ear photosynthesis and photosynthate carbon distribution to water deficit
}

\author{
S. JIA*, J. LV*, ${ }^{* *+}$, S. JIANG ${ }^{* *}$, T. LIANG ${ }^{* *}$, C. LIU**, and Z. JING ${ }^{*}$ \\ College of Science, Northwest A\&F University, Yangling, Shaanxi 712100, China* \\ College of Life Sciences, Northwest A\&F University, Yangling, Shaanxi 712100, China**
}

\begin{abstract}
Understanding distribution and transport of carbon assimilates and photosynthesis contribution to grain yield in wheat spike is important in assessing the photosynthetic process under stress conditions. In this study, photosynthetic characteristics were evaluated in a pot experiment. Transport of spike photosynthates to grain was demonstrated using ${ }^{14} \mathrm{C}$ isotope tracer technique. Yield and key enzyme activities of $\mathrm{C}_{3}$ and $\mathrm{C}_{4}$ pathways were examined after anthesis in wheat cultivars of different drought resistance. The ear net photosynthetic rate, chlorophyll content of the spike bracts (glume, lemma, and palea), and relative water content slightly decreased under water deficit in drought resistant variety Pubing 143 (Pub) during the grain filling stage, whereas all parameters decreased significantly in drought sensitive variety Zhengyin 1 (Zhe). Grain ${ }^{14} \mathrm{C}$-photosynthate distribution rate fell by $3.8 \%$ in Pub and increased by $3.9 \%$ in Zhe. After harvest, the water-use efficiency of Zhe dropped by $18.7 \%$ under water deficit. Rubisco activity in ear organs declined significantly under water deficit, whereas activity of $\mathrm{C}_{4}$ pathway enzymes was significantly enhanced, especially that of phosphoenolpyruvate carboxylase and NADP-malate dehydrogenase. Water deficit exerted lesser influence on spike photosynthesis in Pub. Ear organs exhibited delayed senescence. Accumulation of photosynthetic carbon assimilates in ear bracts occurred mainly during the early grain filling and photosynthates were transported in the middle of grain filling. $\mathrm{C}_{4}$ pathway enzymes seem to play an important function in ear photosynthesis. We speculate that the high enzyme activity of the $\mathrm{C}_{4}$ pathway and the increased capacity of photosynthetic carbon assimilate transport were the reasons for the drought tolerance characteristics of ears.
\end{abstract}

Additional key words: ${ }^{14} \mathrm{C}$-labelling; harvest index; malic enzyme; spike assimilate transport; Triticum aestivum $\mathrm{L}$.

\section{Introduction}

Wheat is the most important food crop in the world. It is also the second largest food crop in China. Drought is the single most important environmental stress that reduces crop yields (Abebe et al. 2010). The challenge facing crop breeders is the creation of food crops with increasing resilience to environmental stresses whilst producing higher yields (Steinmeyer et al. 2013). Wheat leaves, especially flag leaf, are important photosynthetic assimilation organs during a jointing stage and anthesis period. Water deficit affects remobilisation of leaf photosynthetic carbon assimilation, resulting in a decline in yield and water-use efficiency (Xue et al. 2006). Water deficit causes easily a decline in photosynthetic capacity during the wheat grain filling phase, inhibits synthesis of carbon photosynthates after anthesis and their transport to the grain before anthesis, thus reducing wheat grain yields (Zhang et al. 2011).

Wheat flag leaf photosynthesis declines after anthesis; flag leaf photosynthetic rate is almost reduced to the baseline during the late grain filling. Chlorophyll (Chl) contents of nonleaf organs, such as ear, stem, and leaf sheath, slowly decrease, but these organs still exhibit a certain degree of photosynthesis in the late grain filling (Bort et al. 1996). Wheat spike possesses several

Received 10 August 2014, accepted 20 November 2014.

${ }^{+}$Corresponding author; tel: +86029-87092262, e-mail: jinyinlv@nwsuaf.edu.cn

Abbreviations: CA - carbonic anhydrase; CAM - crassulacean acid metabolism; Chl - chlorophyll; DM - dry mass; $E$ - transpiration rate; FM - fresh mass; MDH - malate dehydrogenase; NAD-ME - NAD-malic enzyme; NADP-MDH - NADP-malate dehydrogenase; NADP-ME - NADP-malic enzyme; OD - optical density; PEPC - phosphoenolpyruvate carboxylase; $P_{\mathrm{N}}-$ net photosynthetic rate; PPDK - pyruvate orthophosphate dikinase; RWC - relative water content; TM - turgid mass; WUE - water-use efficiency.

Acknowledgements: This study is supported by projects of the National Natural Science Foundation of China (31271624). We thank Professor Puling Liu for the technical assistance.

(C) The Author(s). This article is published with open access at link.springer.com 
advantages, which include vast space for receiving light and $\mathrm{CO}_{2}$, strong ability of osmotic adjustment, and higher water potential and maintenance of a relatively high photosynthetic rate under drought conditions (Tambussi et al. 2007). Existing studies show that nonleaf organs are resistant to water deficit, and are important sources of photosynthetic carbon assimilation under drought condition during the grain filling phase (Bort and Febrero 1994, Sánchez-Díaz et al. 2002, Kong et al. 2010). After flowering, the contribution of ear photosynthesis to grain yields begins to rise (Araus et al. 1993, Zhang et al. 2003, Maydup et al. 2010, 2012). Spike organs can obtain and refix $\mathrm{CO}_{2}$ respired by developing grains, thus, spike photosynthesis has obvious physical advantages (Wang et al. 2004, Zhang et al. 2009). However, the disparity of spike photosynthesis remains unclear in different drought resistant varieties under water deficit.

Carbon isotope tracer is widely used in the study of plant photosynthesis and respiration (Nguyen et al. 1999, Ekblad and Högberg 2000, Ostle et al. 2000, Kuzyakov and Domanski 2002, Thornton et al. 2004, Matsuhashi et al. 2006, Comstedt et al. 2007, Sanchez-Bragado et al. 2014). Photosynthetic C-labelling of wheat flag leaves and intact plants using carbon isotopes $\left({ }^{14} \mathrm{C},{ }^{13} \mathrm{C}\right)$ is the main technique in studying the distribution of carbon assimilates. Sanchez-Bragado (2014) studied the spike contribution to grain amongst different varieties using ${ }^{13} \mathrm{C}$-labelling. We have studied ${ }^{14} \mathrm{C}$-photosynthate distribution before and after anthesis, and results show that moderate water deficit can raise the spike carbon assimilation activity of wheat and accelerate photosynthate transport to grain in early grain filling, with subsequent maintenance of relatively high grain yields (Ren et al. 2012, Zhang et al. 2013). However, factors involved in influencing grain yields during the midgrain filling stage under drought remain elusive, such as photosynthate distribution, transport, and contribution rate to grain yields of wheat.

In wheat, the ear green organs have higher potential photosynthetic efficiency compared to the leaf. Numerous pieces of evidence suggest that spike photosynthesis metabolism is similar to the $\mathrm{C}_{4}$ pathway or belongs to the $\mathrm{C}_{3}-\mathrm{C}_{4}$ intermediate type (Singal et al. 1986, Araus 1993,

\section{Materials and methods}

Plant material and experimental setup: Two winter wheat (Triticum aestivum $\mathrm{L}$.) varieties were studied under controlled environment conditions. Pubing 143 (Pub) was approved by Shaanxi province in September 2004 as the drought resistant variety suitable for dry land cropping, whereas Zhengyin 1 (Zhe) was introduced by Henan Academy of Agricultural Sciences from Italy in 1980s (introduction name: st1472/506) as the drought sensitive variety suitable as a plain cultivar.

Pot experiment was carried out from October 2012 to June 2013 in the North Campus of Northwest A\&F Uni-
Bort et al. 1995), which is more apparent under drought condition. Rubisco, a key enzyme of $\mathrm{C}_{3}$ plants, can be used as a metabolic indicator of drought tolerance in wheat (Nagy et al. 2013). Rubisco without the Calvin cycle improves carbon-use efficiency in developing green seeds (Schwender et al. 2004). Contrary to the $\mathrm{C}_{3}$ pathway, the $\mathrm{C}_{4}$ pathway is not studied well in wheat, especially, the question how the key enzymes of the spike $\mathrm{C}_{4}$ cycle are regulated under different stressors (drought, heat, salt, etc.). Phosphoenolpyruvate carboxylase (PEPC), the key enzyme of the $\mathrm{C}_{4}$ pathway, is efficiently expressed in wheat seedling roots and leaves (Osuna et al. 1996, González et al. 1998, 2002, 2003). Some PEPCs of $\mathrm{C}_{3}$ gramineous plants do not only have a similar structure to that of maize PEPC, but they are also regulated by light in a similar manner (Matsuoka and Hata 1987). They have an important function in grain formation and grouting protein accumulation (Davood and Alireza 2011, Zhang et al. 2012). Carbonic anhydrase (CA) possibly functions in $\mathrm{C}_{4}$ photosynthesis at the dough stage in wheat plants (Li et al. 2004). Studies on NAD-malic enzyme (NADME), NADP-malic enzyme (NADP-ME), NADP-malate dehydrogenase (MDH), and pyruvate Pi dikinase (PPDK) are focused on the physiology and protein expression in wheat seedling leaves (Aoyagi and Bassham 1983, 1984a,b; Gajewska et al. 2013). The other key enzymes of the $\mathrm{C}_{4}$ pathway have equal effects on PEPC in wheat spike bracts (glume, lemma, and palea), but they remain scarcely researched. However, no reports on the $\mathrm{C}_{4}$ pathway in spike photosynthesis exist (Bort et al. 1995, Tambussi et al. 2007), and necessary evidence that the $C_{4}$ pathway occurs in ear photosynthesis is still lacking.

This study is mainly focused on investigating ear net photosynthetic rate $\left(P_{\mathrm{N}}\right)$, carbon assimilate transport, their contribution to the grain yield in the middle grain filling, and the activity of $\mathrm{C}_{4}$ pathway enzymes under water deficit in different drought resistant wheat varieties. Different enzyme activities of the $\mathrm{C}_{4}$ pathway and bract contribution to grain are studied. To fully understand the photosynthetic carbon fixation potential of ear and the physiological basis of dry land wheat to sustain yields, we determined the photosynthetic characteristics and photosynthate carbon distribution rate of ear to grain yields.

versity, Yangling $\left(34^{\circ} 17^{\prime} \mathrm{N}, 108^{\circ} 4^{\prime} \mathrm{E}\right)$, Shaanxi Province, China. Soil was collected from Shaanxi (local red loessial soil) with a soil net water content of $29.2 \%$ at the largest field water capacity. Plastic pots with an upper diameter of $24 \mathrm{~cm}$, bottom diameter of $17 \mathrm{~cm}$, and height of $24 \mathrm{~cm}$ were filled with $7 \mathrm{~kg}$ of soil. Before sowing, an equivalent of $0.347 \mathrm{~g}$ (urea) $\mathrm{kg}^{-1}$ (soil) and $0.2 \mathrm{~g}\left(\mathrm{~K}_{2} \mathrm{HPO}_{3}\right) \mathrm{kg}^{-1}$ (soil) were incorporated into the soil in each pot. Twenty seeds were sown in each pot on 17 October 2012, and the seedlings were thinned to 12 plants per pot after germination. The main stem was left with removed tillers on the 
jointing stage. Normal water supply and water deficit treatment were carried out through the soil with a moisture content of 70 to $75 \%$ (respective control, CK) and 45 to $50 \%$ (moderate water deficit, MD) of the largest field water capacity, respectively. Water control began on the late elongation stage (April 6, 2013) by weighing method using irrigation as the water control standard every day with 15 replicates.

Spike $P_{\mathrm{N}}$, transpiration rate $(E)$, Chl content, and relative water content (RWC): Spike $P_{\mathrm{N}}$ and $E$ were measured by a portable photosynthetic apparatus (LI-6400 $X T$, LiCor, USA) with a special cylindrical measuring chamber from 9 to $11 \mathrm{~h}$ at $0,6,12,18$, and $24 \mathrm{~d}$ after anthesis (DAA) with four replicates. Spike surface area was calculated according to the formula of the fringe area (Teare and Peterson 1971).

The Chl content of glume, lemma (containing awn), and palea were determined at $0,6,12,18$, and 24 DAA following the study by Pang et al. (2013) with slight modifications. A $0.1 \mathrm{~g}$ sample was finely cut, placed in a tube with stopper, and added with $10 \mathrm{~mL}$ of $80 \%$ acetone. Samples were immediately placed in the dark for $48 \mathrm{~h}$. A $3 \mathrm{~mL}$ of the extract was obtained to measure the optical density (OD) using a UV/VIS spectrometer (UV757CRT, Shanghai Precision Scientific Instrument Co., Ltd., China) at 645 and $663 \mathrm{~nm}$. Analyses were carried out in quadruplicates. The total $\mathrm{Chl}$ content was calculated as 8.020D $663+20.21 \mathrm{OD}_{645}$ and expressed in $\mathrm{mg} \mathrm{g}^{-1}(\mathrm{FM})$.

RWC was measured according to $\mathrm{Hu}$ et al. (2013). Fresh mass (FM) of glume, lemma, and palea was weighed followed by soaking the samples for $4 \mathrm{~h}$ in distilled water at room temperature. After this treatment, the turgid mass (TM) was recorded. Leaves were then dried for $24 \mathrm{~h}$ at $80^{\circ} \mathrm{C}$ to obtain the total dry mass (DM). RWC was calculated from the equation:

$$
\mathrm{RWC}[\%]=[(\mathrm{FM}-\mathrm{DM}) /(\mathrm{TM}-\mathrm{DM})] \times 100 \text {. }
$$

Extraction and assays of key enzymes of $\mathrm{C}_{3}$ and $\mathrm{C}_{4}$ pathway: The glume, lemma, and palea was obtained on $0,6,12,18$, and $24 \mathrm{DAA}$ at 10 a.m., quickly frozen in liquid nitrogen, and stored at $-80^{\circ} \mathrm{C}$ in a freezer. Enzyme activity was measured after all sample collection.

Enzyme extraction was carried out according to the method of Sayre et al. (1979) with modifications. A $0.5 \mathrm{~g}$ tissue was ground using a mortar and pestle at $4{ }^{\circ} \mathrm{C}$, and then $4 \mathrm{~mL}$ of grinding media, composed of $0.1 \mathrm{M}$ Tris$\mathrm{HCl}$ (pH 7.8), $10 \mathrm{mM} \mathrm{MgCl}, 20 \mathrm{mM}$ mercaptoethanol, $1.0 \mathrm{mM}$ EDTA, and 2\% (w/v) polyvinylpyrrolidone-10, was added. Glume, lemma, and palea extracts were centrifuged at $15,000 \times g$ for $10 \mathrm{~min}$ at $4^{\circ} \mathrm{C}$. The supernatant was used for the Rubisco, PEPC, NAD-ME, NADP-ME, NADP-MDH, and PPDK assays. The assays were run at $25^{\circ} \mathrm{C}$, and the rates were expressed on protein basis in mol(substrate) $\mathrm{min}^{-1} \mathrm{mg}^{-1}$ (protein).

Rubisco (EC 4.1.1.39) activity measurements were carried out following the work of Camp et al. (1982).
Enzyme extract was added to the reaction mixture, which contained $50 \mathrm{mM}$ Tricine- $\mathrm{NaOH}$ (pH 7.9), $15 \mathrm{mM} \mathrm{MgCl}_{2}$, $10 \mathrm{mM} \mathrm{NaHCO}, 2 \mathrm{mM}$ DTT, $10 \mathrm{mM} \mathrm{KCl}, 0.2 \mathrm{mM}$ $\mathrm{NADH}, 1 \mathrm{mM}$ EDTA, $4 \mathrm{U} \mathrm{mL}^{-1}$ 3P-glycerate kinase (Sigma), $2 \mathrm{U} \mathrm{mL}^{-1}$ creatine phosphokinase (Sigma), $5 \mathrm{mM}$ phosphocreatine (Sigma), $5 \mathrm{mM}$ ATP, $4 \mathrm{U} \mathrm{mL}^{-1}$ glyceraldehyde-3P-dehydrogenase (Sigma) with a final volume of $3 \mathrm{~mL}$. Reactions were initiated by adding $0.5 \mathrm{mM}$ RuBP.

Activity of PEPC (EC 4.1.1.31) was spectrophotometrically monitored as the reduction of $\mathrm{NADH}$ at $340 \mathrm{~nm}$ according to Blanke and Ebert (1992) with minor modifications. Enzyme extract was added to a reaction mixture, which contained $50 \mathrm{mM}$ Tris- $\mathrm{HCl}(\mathrm{pH} 7.8)$, $10 \mathrm{mM} \mathrm{MgCl}_{2}, 0.25 \mathrm{mM}$ EDTA, $0.1 \mathrm{mM}$ NADH, $5.0 \mathrm{mM}$ $\mathrm{NaHCO}_{3}, 2.0 \mathrm{mM}$ DTT, 4U MDH (Sigma), and $2.0 \mathrm{mM}$ phosphoenolpyruvate (Sigma), with a final volume of $3 \mathrm{~mL}$. The reaction commenced with the addition of the crude enzyme extract.

NAD-ME (EC 1.1.1.38) and NADP-ME (EC 1.1.1.40) activities were spectrophotometrically monitored as the reduction of NADH at $340 \mathrm{~nm}$ according to Sayre et al. (1979). Assays were carried out in $3 \mathrm{~mL}$ cuvettes containing $2.5 \mathrm{mM}$ Tris- $\mathrm{HCl}(\mathrm{pH} 8.3), 2.5 \mathrm{mM}$ malate, $0.5 \mathrm{mM}$ EDTA, crude enzyme extract, and either $2.0 \mathrm{mM}$ NAD or $0.25 \mathrm{mM}$ NADP with $0.75 \mu \mathrm{M}$ CoA. NAD-ME reactions began by the addition of $5.0 \mathrm{mM} \mathrm{MnCl}_{2}$. NADP-ME assays were initiated by $5.0 \mathrm{mM} \mathrm{MgCl}_{2}$.

NADP-MDH (EC 1.1.1.37) activity was spectrophotometrically monitored as the oxidation of NADH at $340 \mathrm{~nm}$ according to Sayre et al. (1979) with slight modifications. The reaction cuvette contained $100 \mathrm{mM}$ Tricine ( $\mathrm{pH}$ 7.5), $0.1 \mathrm{mM}$ NADH, $0.2 \mathrm{mM}$ EDTA, and crude enzyme extract. Oxaloacetic acid was added to initiate the reaction after determining the basal rate of NADH oxidation.

PPDK (EC 2.7.9.1) activity was spectrophotometrically assayed according to Sayre et al. (1979). Reaction cuvettes contained $0.1 \mathrm{M}$ Tris- $\mathrm{HCl}(\mathrm{pH} 8.0), 1.25 \mathrm{mM}$ pyruvate, $10 \mathrm{mM} \mathrm{MgCl}_{2}, 5.0 \mathrm{mM}$ DTT, $0.1 \mathrm{mM}$ EDTA, $2.5 \mathrm{mM} \mathrm{K}_{2} \mathrm{KPO}_{4}, 0.16 \mathrm{mM} \mathrm{NADH}, 50 \mathrm{mM} \mathrm{NaHCO}$, $3 \mathrm{U}$ of malate dehydrogenase (Sigma), $2 \mathrm{U}$ of corn PEPC (Sigma), and crude enzyme extract. Reactions were started after a 3 min preincubation with $1.25 \mathrm{mM} \mathrm{ATP}$, and NADH oxidation was monitored at $340 \mathrm{~nm}$.

The CA (EC 4.2.1.1) activity assay was carried out according to the method of Brownell et al. (1991) with minor modifications. The method is based on the methods of Tsuzuki et al. (1985) and Moroney et al. (1985). A $0.5 \mathrm{~g}$ of tissue was ground at $4^{\circ} \mathrm{C}$ using a mortar and pestle and $4 \mathrm{~mL}$ of grinding media (containing $10 \mathrm{mM}$ barbital buffer, $5 \mathrm{mM}$ mercaptoethanol, $\mathrm{pH}$ 8.2). Glume, lemma, and palea extracts were centrifuged at $16,000 \times g$ for $20 \mathrm{~min}$ at $4^{\circ} \mathrm{C}$. The supernatant was used as the crude enzyme extract, whereas the boiled sample served as blank. CA activity was measured at $4{ }^{\circ} \mathrm{C}$ in a cold reaction chamber by adding $5 \mathrm{~mL}$ of buffer $(20 \mathrm{mM}$ barbitone $\mathrm{KOH}, \mathrm{pH} 8.4$ ) and $0.5 \mathrm{~mL}$ of the crude enzyme extract or boiling sample with uniform mixing using a 
magnetic stirrer, and then $4.5 \mathrm{~mL}$ of cold $\mathrm{CO}_{2}$-saturated water $\left(\mathrm{CO}_{2}\right.$ gas filling $0^{\circ} \mathrm{C}$ ice water mixture for $\left.1 \mathrm{~h}\right)$ is injected. The time needed for $\mathrm{pH}$ to decrease from 8.4 to 7.4 was monitored using a Lei-ci pH meter (PHS-3C, Shanghai REX Instrument Factory, China). CA activity is expressed in units $\mathrm{mg}^{-1}$ (protein) and was calculated using the formula $\left[10\left(\mathrm{~T}_{0} / \mathrm{T}-1\right)\right] / \mathrm{mg}$ of protein, where the $\mathrm{T}_{0}$ and $\mathrm{T}$ were the time ( $\mathrm{min}$ ) of $\mathrm{pH}$ changes for the boiled sample and crude enzyme extract assay, respectively. The assay was carried out in triplicates.

${ }^{14} \mathrm{C}$ photosynthate determination in spike bracts labelled by ${ }^{14} \mathrm{CO}_{2}$ : For each treatment, 30 plants were marked by ${ }^{14} \mathrm{CO}_{2}$ at 10 DAA. Six plants per treatment were obtained at 10, 15, 20, 25, and 30 DAA. Spikes were trapped using a polyethylene plastic bag and sealed at 9:00 a.m., $5 \mathrm{~mL}$ of ${ }^{14} \mathrm{CO}_{2}$ was injected with a syringe, which had $81.77 \times 10^{4} \mathrm{~Bq} \mathrm{~L}^{-1} \mathrm{CO}_{2}$ intensity. Residual ${ }^{14} \mathrm{CO}_{2}$ was recycled through $\mathrm{NaOH}$ solution after $1 \mathrm{~h}$ labelling.

Spike was separated as grain, glume, lemma, palea, and rachis, excised for $15 \mathrm{~min}$ at $105^{\circ} \mathrm{C}$, and dried to constant mass in $70^{\circ} \mathrm{C}$ oven. A $50 \mathrm{mg}$ of the ground samples was weighed and added with a $0.5 \mathrm{~mL}$ of $60 \%$ $\mathrm{HClO}_{4}$ and $0.7 \mathrm{~mL}$ of $30 \% \mathrm{H}_{2} \mathrm{O}_{2}$. After digestion for $4 \mathrm{~h}$ at $70^{\circ} \mathrm{C}, 10 \mathrm{~mL}$ of liquid scintillation (Ready-Solv, Beckman, USA) was added and placed in a dark place overnight. The test above was repeated four times (Zhang et al. 2013). With multifunctional liquid scintillation counting system (LS-6500, Beckman, USA), the total radioactivity was determined using the cpm value, calculating the natural decay value $(\mathrm{dpm})$ through counting efficiency correction. ${ }^{14} \mathrm{C}$ photosynthate distribution ratio in different organs was calculated as certain organ radioactivity $(\mathrm{dpm}) /$ spike total radioactivity $(\mathrm{dpm}) \times 100[\%]$.

Dry matter accumulation changes of wheat spike: Sampling was conducted at 10 a.m. on 10, 15, 20, 25, and 30 DAA at ten spikes per sampling. The spike was excised for $15 \mathrm{~min}$ at $105^{\circ} \mathrm{C}$, separated as grain, glume, lemma, palea, and rachis and oven dried to constant mass at $70^{\circ} \mathrm{C}$. Dry matter accumulation ratio was calculated as follows: dry matter $[\%]=$ certain organ mass $[\mathrm{g}] / \mathrm{spike}$ mass $[\mathrm{g}] \times 100$.

Agronomic traits and water-use efficiency (WUE): After wheat harvest, the plants of selected pots for each treatment were collected. Different parameters were obtained, namely, altitude, spike length, spike grain number, fertile spikelets, total spikelets, kernels per ear, mass per ear, 1000-kernel mass, and grain yield. Harvest index $(\mathrm{HI})$ was calculated as: $\mathrm{HI}=$ grain yield per pot $[\mathrm{g}] /$ whole plant biomass per pot $[\mathrm{g}]$.

Sampling was conducted at 2, 6, 12, 18, 24, 32, and 32 DAA, 10 spikes per sample, and peeled grains were counted. Excised grains converted into 1000-kernel mass. To analyse the grain filling rate, average values of 1000-kernel mass were described by a logistic equation as follows:

$$
\mathrm{W}=\mathrm{A} /\left(1+\mathrm{B} \mathrm{e}^{-\mathrm{kt}}\right)
$$

where $\mathrm{W}$ is the average 1000-kernel mass [g] and $\mathrm{t}$ is DAA. The term A estimates the final 1000-kernel mass [g], B is a constant codetermined by both rate and duration of grain filling and $\mathrm{k}$ is a constant depending on the grain filling rate. The estimates of $\mathrm{A}, \mathrm{B}$, and $\mathrm{k}$ were determined using the nonlinear regression procedure from the Matlab mathematical software (Matlab 2012b, USA). Two critical values, 10 and $90 \%$, of the final 1000-kernel mass were taken to divide the wheat grain into three growth periods, which include the growing phase, fast increasing phase, and slow increasing phase (Fig. 1). Parameters of the beginning $\left(\mathrm{t}_{1},[\mathrm{~d}]\right)$ and the end day of fast increasing phase $\left(\mathrm{t}_{2},[\mathrm{~d}]\right)$, i.e. maximum grain filling period, estimated maximum grain filling rate $\left(\mathrm{V}_{\max },[\mathrm{mg}\right.$ $\left.\mathrm{d}^{-1}\right]$ ), estimated maximum grain filling duration $(\mathrm{T},[\mathrm{d}])$, and the estimated maximum grain filling time ( $\mathrm{t}_{\max }$, [DAA]) were calculated from the regression lines ( $\mathrm{Li}$ et al. 2013).

WUE was calculated on the basis of yield: WUE = grain yield per pot $[\mathrm{g}] /$ total water consumption $[\mathrm{kg}]$.

Statistical analysis: Data were subjected to analysis of variance (ANOVA). Duncan's multiple range analysis was used to determine the significant differences between treatments using SPSS statistical software (SPSS 17.0). Error bars represent percentage errors (SE). Fitting analysis of grain filling logistic equation was based on Matlab mathematical software. Figures were completed using OriginPro 8.5.

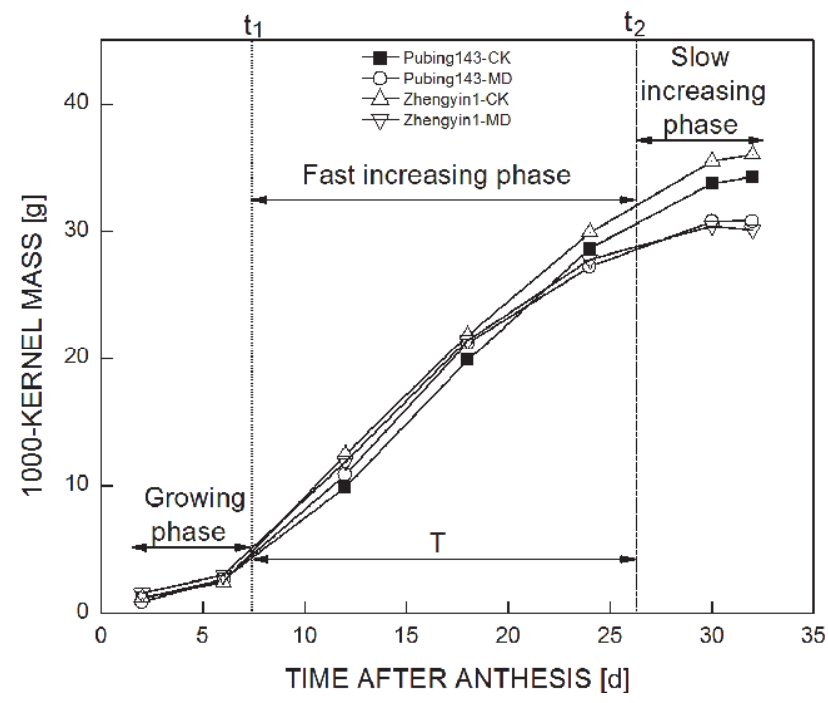

Fig. 1. Effects of water deficit on the grain filling in different wheat cultivars (Pubing 143 - drought-resistant cultivar, Zhengyin 1- drought-sensitive cultivar). CK - control with normal water supply; MD - moderate water deficit. 


\section{Results}

Spike and flag leaf $\boldsymbol{P}_{\mathrm{N}}$ and spike $\mathrm{Chl}$ content: The ear $P_{\mathrm{N}}$ of two tested varieties significantly increased at the begining of spike bracts growth (6 DAA), and steadily decrased thereafter (Fig. 2A). At the flowering period (0 DAA), compared with respective $\mathrm{CK}$ (i.e. normal water supply), the ear $P_{\mathrm{N}}$ increased by $10.6 \%$ under water deficit in Pub, whereas Zhe was reduced by $16.9 \%$. At 12 , 18, and 24 DAA, ear $P_{\mathrm{N}}$ declined significantly in Pub, whereas it dropped faster in Zhe. $P_{\mathrm{N}}$ differences between two varieties occurred mainly in the early grain filling stage under water deficit; the spike of Zhe was more sensitive to water deficit.

The flag leaf $P_{\mathrm{N}}$ was reduced markedly in both tested varieties. The ear $P_{N}$ was reduced significantly only at 12 , 18, and 24 DAA in Pub, whereas it declined during the whole grain filling stage in Zhe. The flag leaf $\mathrm{P}_{\mathrm{N}}$ was more sensitive to water deficit in Zhe (Fig. $2 B$ ).

Glume and lemma receive light because of their location outside the spikelets, thus, they showed a higher Chl content than palea, which is relatively low wrapped by lemma. Under water deficit, glume Chl content fell by $20.2 \%$ at 24 DAA in Pub, whereas it declined by $27.7 \%$ in Zhe (Fig. 3A). The lemma Chl content dropped more in Zhe $(22.2 \%)$ than in Pub (14.6\%) after 24 DAA under drought condition (Fig. 3B). The palea Chl content decreased by $16.8 \%$ in Pub at 24 DAA, whereas it dropped by $65.5 \%$ in Zhe under water deficit (Fig. 3C). To maintain a relatively high $P_{\mathrm{N}}$, the drop scale of the Chl content of ear bracts in Pub was lower than in Zhe under water deficit.

$\boldsymbol{E}$ and RWC: $E a r E$ was reduced slightly in Pub at 0 and 6 DAA under water deficit, and then fell by $28.7 \%$ at 24 DAA. It dropped significantly by $41.3 \%$ at 24 DAA (Fig. 2C) in Zhe compared with the normal water supply. The water deficit affected the ear $E$ mainly in the late grouting period; the effect on $E$ was more significant in spike of Zhe than in Pub.

Glume RWC decreased by $11.8 \%$ in Pub just at 18 DAA under water deficit. No significant difference of glume RWC was observed in other stages; in Zhe, RWC fell by $19.5 \%$ on 24 DAA (Fig. $3 D$ ), showing that the glume had a higher water retention than that in Pub. The lemma RWC of both varieties showed no significant difference under drought condition (Fig. 3E). Palea RWC increased by $18.3 \%$ in Pub at the flowering period, and then dropped slightly under water deficit. In Zhe, it decreased by $34.8 \%$ on 24 DAA (Fig. $3 F$ ). Thus, spike RWC decreased less in Pub than in Zhe, indicating that Pub retained relatively higher moisture retention ability than Zhe.

Spike carbon assimilation enzyme activity: Rubisco activity in bracts increased in the early grouting and decreased after then (Fig. 4). Under water deficit, Pub glume Rubisco activity fell by $37.8 \%$ in the middle of the grouting period (12 DAA), while the decline in the remaining periods was not obvious. In Zhe, it declined

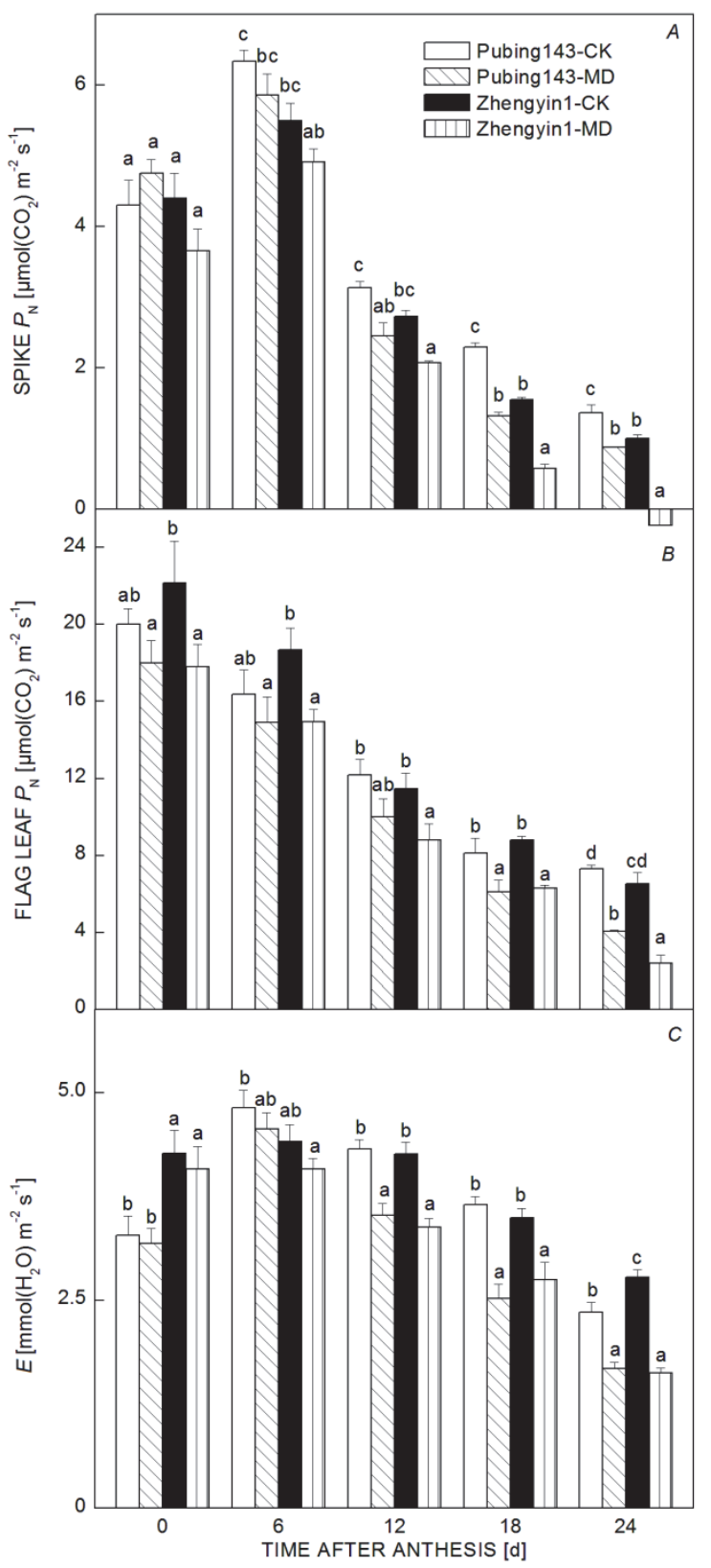

Fig. 2. Effect of water deficit on net photosynthetic rate $\left(P_{\mathrm{N}}\right)$ of spikes $(A)$ and flag leaf $(B)$, and transpiration rate $(E)$ of spikes (C) after anthesis in wheat (Pubing 143 - drought-resistant cultivar, Zhengyin 1 - drought-sensitive cultivar). Data are presented as means \pm standard errors of three biological replicates. Different letters indicate significant difference among treatments on the same sampling day according to the Duncan's multiple range test $(P<0.05)$. CK - control with normal water supply; MD - moderate water deficit. Error bars indicate $\pm \mathrm{SE}$. 


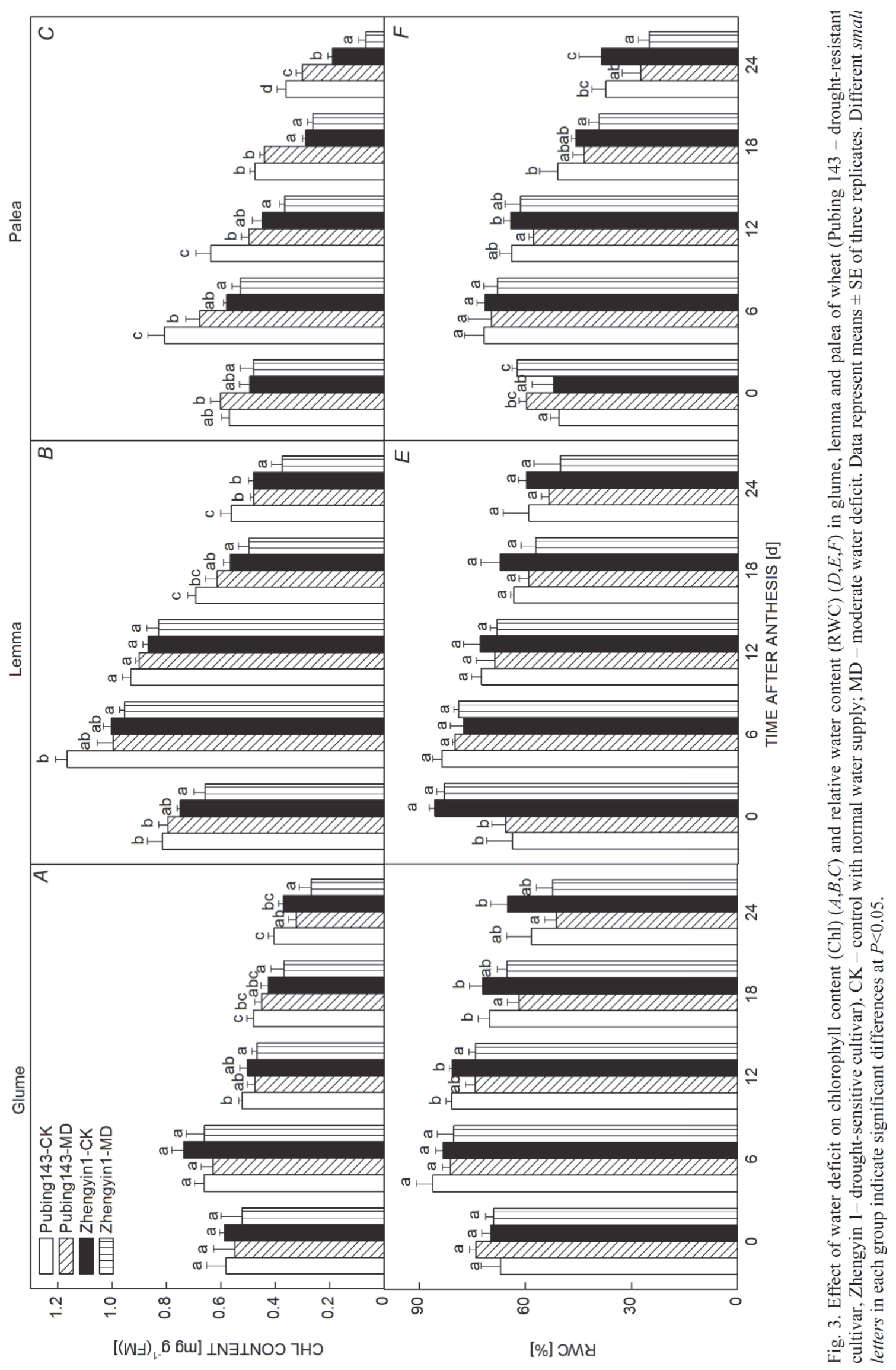


significantly from $0 \mathrm{DAA}$ to $18 \mathrm{DAA}$, especially at 18 DAA, when the reduction of $45.6 \%$ was observed (Fig. 4A). Under drought, lemma Rubisco activity in Pub decreased by 24.7 and $30.3 \%$ at 12 and 18 DAA, respectively, whereas in Zhe it fell significantly from 12 DAA to 24 DAA, with the highest reduction of $45.3 \%$ at 24 DAA (Fig. 4B). Under water deficit, Pub palea Rubisco activity fell by $15.1 \%$ on 12 DAA, whereas in Zhe it decreased by 22.4 and $28.5 \%$ at 12 and 24 DAA, respectively (Fig. 4C). Rubisco activity showed similar trends in spike photosynthesis. The highest activity was found in ear green organs at the grain filling stage, and enzyme activity of Pub was less sensitive to water stress.

Under water deficit, Pub glume CA activity increased by 47.5 and $38.4 \%$ at 0 and 6 DAA, respectively, and slightly increased in Zhe (Fig. 4D). Under drought stress, lemma CA activity significantly increased during 12 DAA to 24 DAA in Pub with the highest increase of $85.2 \%$ at 18 DAA. In contrast, Zhe CA activity rose by 78.6 and $72.0 \%$ at 18 and 24 DAA, respectively (Fig. $4 E$ ). Palea CA activity of Pub rose by $34.6 \%$ at 6 DAA under drought condition, but this was not obvious at the grain filling stage in Zhe (Fig. 4F). CA enzyme activity was relatively high in ear green parts during the grain filling phase, it increased in ear bracts, and it was considerably augmented in Pub under water deficit.

Glume PEPC activity significantly rose during 12 to 24 DAA in Pub under water deficit, with a $57.3 \%$ increase at 24 DAA, whereas it rose by $60.8 \%$ just on 18 DAA in Zhe (Fig. 4G). Under drought stress, lemma PEPC activity increased by $37.9,84.3$, and $83.8 \%$ in Pub at 12,18 , and 24 DAA, respectively, whereas Zhe showed no significant increase (Fig. 4H). Palea PEPC activity increased significantly during the grain filling stage in Pub under water deficit, whereas Zhe showed opposite trend (Fig. 4I). The enzyme activity of Pub significantly increased under water deficit, showing that $\mathrm{C}_{4}$ pathway key enzyme might have an important function in carbon retention during spike photosynthesis.

Under drought conditions, NADP-MDH activity dropped from 6 DAA in glume and palea and declined gradually in lemma during the grain filling stage as shown in Fig. 5. Glume NADP-MDH activity increased by 27.2 , 47.2, and $90.0 \%$ in Pub at 6, 18, and 24 DAA, respectively. However, NADP-MDH activity increased only by $8.2 \%$ at 18 DAA in Zhe (Fig. $5 A$ ). Lemma NADP-MDH activity rose significantly in Pub from $0 \mathrm{DAA}$ to $18 \mathrm{DAA}$, showing the highest increase of $65.1 \%$ at $18 \mathrm{DAA}$, whereas in Zhe it rose by $51.4 \%$ at 18 DAA (Fig. $5 B$ ). Palea NADP-MDH activity increased by 94.4 and $86.0 \%$ in Pub at 18 and 24 DAA, respectively, while it rose in Zhe by 22.1 and $48.8 \%$ at 6 and 24 DAA, respectively (Fig. 5C). Compared to the other enzymes, NADP-MDH activity was much higher in ear green organs. The enzyme activity of Pub increased significantly under drought stress.

Glume NADP-ME activity rose by 56.3 and $59.3 \%$ in Pub at 18 and 24 DAA, respectively, under water deficit, whereas it rose by $25.7 \%$ only at 18 DAA in Zhe (Fig. $5 D$ ). Under drought stress, lemma NADP-ME activity significantly rose in Pub from 12 to 24 DAA, with the highest increase of $87.6 \%$ at $24 \mathrm{DAA}$, whereas Zhe showed no significant increase (Fig. 5E). Under water deficit, palea NADP-ME activity significantly rose in Pub from 6 to 18 DAA, particularly by $70.8 \%$ at 18 DAA, whereas it increased by 21.8 and $41.9 \%$ at 12 and 18 DAA in Zhe, respectively (Fig. $5 F$ ). NADP-ME activity rose significantly in the chloroplasts of ear bracts. Compared with Zhe, the enzyme activity of Pub increased significantly under water deficit.

Variations in NAD-ME activity were similar to NADP-ME activity (Fig. 6A-C). Under water deficit, glume NAD-ME activity significantly increased in Pub during the grain filling stage, with the highest increase of $94.6 \%$ at 24 DAA, whereas it rose in Zhe by $54.9 \%$ only at 24 DAA (Fig. 6A). Under water deficit, lemma NAD-ME activity of Pub increased by 18.2 and $63.1 \%$ at 12 and 24 DAA, respectively, whereas it increased only slightly in Zhe (Fig. 6B). Under drought condition, palea NAD-ME activity increased by 46.4 and $85.8 \%$ in Pub at 12 and 18 DAA, respectively, whereas it rose by $30.8 \%$ at 12 DAA in Zhe (Fig. 6C). The NAD-ME was found in the mitochondria of bracts. The enzyme activity of Pub rose more significantly than that of Zhe.

One of the key enzymes of the $\mathrm{C}_{4}$ pathway, PPDK, showed a decrease from 6 DAA in glume, lemma, and palea during the grain filling stage (Fig. $6 D-F$ ). Under water deficit, glume PPDK activity rose by $45.7 \%$ in Pub during the late grouting period, whereas it was opposite in Zhe (Fig. 6D). Under drought condition, lemma PPDK activity rose by $28.1 \%$ in Pub only at 24 DAA, whereas no significant change was observed in Zhe during the grain filling stage (Fig. $6 E$ ). Palea PPDK activity rose by $14.8 \%$ in Pub at 6 DAA under water deficit. In contrast, no significant changes were observed in PPDK activity of Zhe (Fig. 6F). PPDK was present in spike green parts at the grain filling stage. Compared with Zhe, the enzyme activity of Pub increased significantly under water deficit.

Spike ${ }^{14} \mathrm{C}$-photoassimilate transport and distribution: During the harvest period (30 DAA), ${ }^{14} \mathrm{C}$-photosynthate accumulation in seeds reached from 76.3 to $84.8 \%$ under both water treatments; it reached maximum at $25 \mathrm{DAA}$ (15 d after labelling). The distribution ratio of ${ }^{14} \mathrm{C}$-photosynthate was 80.9 and $77.0 \%$ in grain of Pub and Zhe, respectively. On harvest, grain ${ }^{14} \mathrm{C}$-photosynthate accumulation was significantly higher in Pub than in Zhe. The grain distribution rate of ${ }^{14} \mathrm{C}$-photosynthates was reduced 


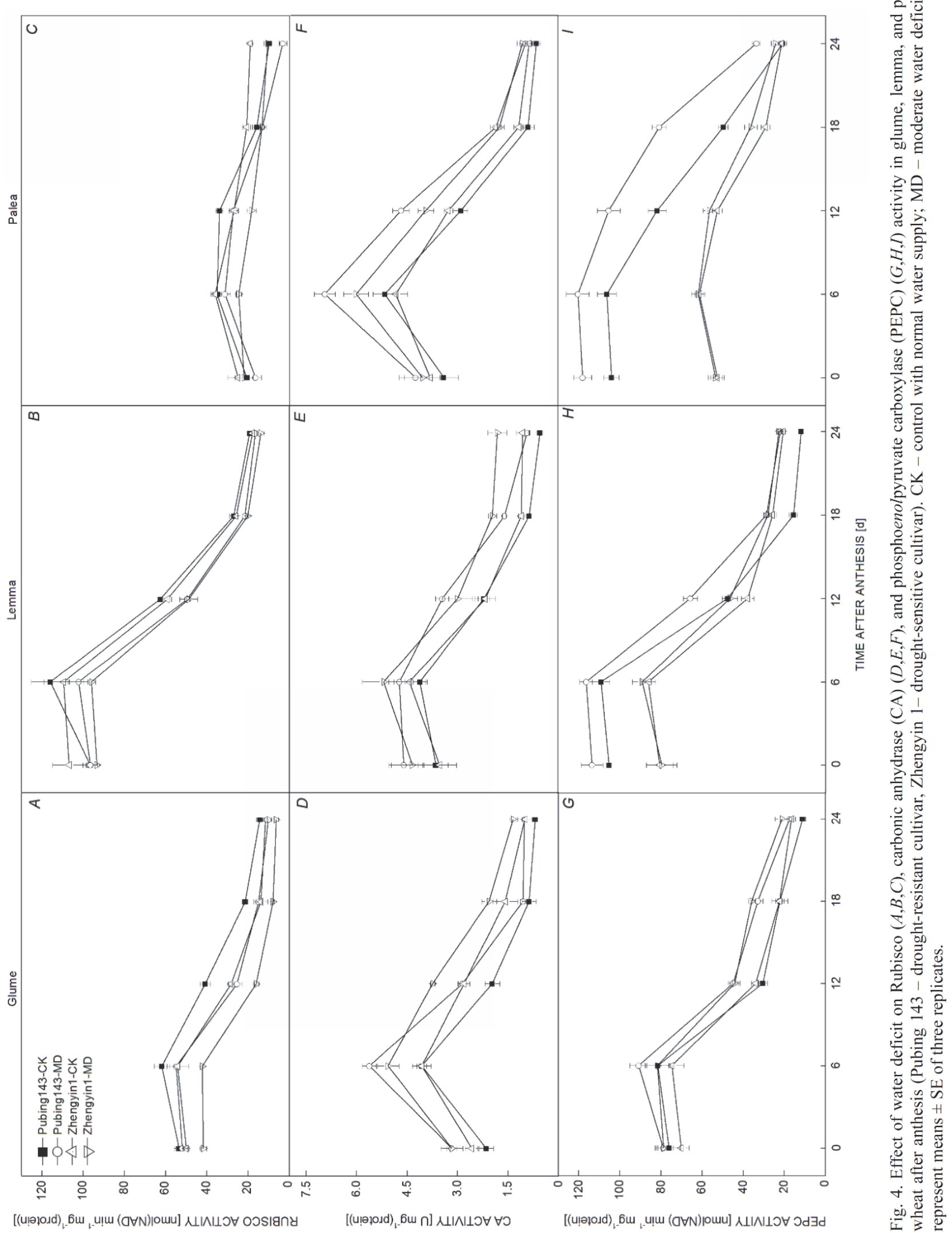




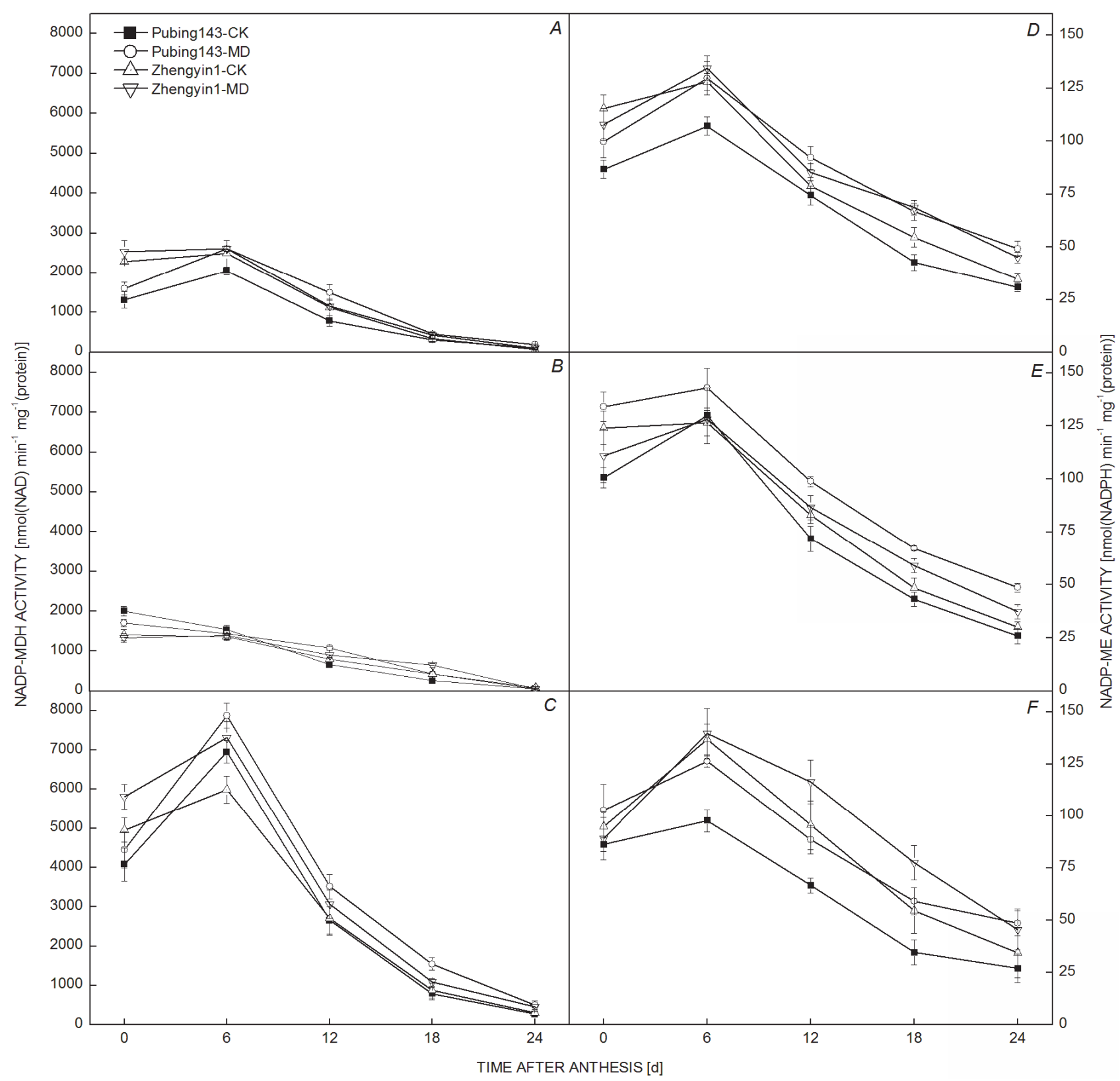

Fig. 5. Effect of water deficit on NADP-malate dehydrogenase (NADP-MDH) $(A, B, C)$ and NADP-malic enzyme (NADP-ME) ( $D, E, F)$ activity in glume $(A, D)$, lemma $(B, E)$, and palea $(C, F)$ of wheat after anthesis (Pubing 143 - drought-resistant cultivar, Zhengyin 1drought-sensitive cultivar). $\mathrm{CK}$ - control with normal water supply; MD - moderate water deficit.

by $3.8 \%$ in Pub under water deficit, whereas it increased by $3.9 \%$ in Zhe. This might result from the promotion of photoassimilate transport from the glume, lemma, and palea to the grain in Zhe under water deficit. By contrast, the influence of water deficit on Pub was not obvious (Fig. 7A).

From 10 to $25 \mathrm{DAA}$, glume ${ }^{14} \mathrm{C}$-photosynthate was quickly withdrawn. After $25 \mathrm{DAA}$, the distribution rate of ${ }^{14} \mathrm{C}$-photosynthate was constant in glume, which indicated that most of ${ }^{14} \mathrm{C}$-photosynthate had been completely transferred at 25 DAA. On harvest (30 DAA), the ${ }^{14} \mathrm{C}$-photosynthate distribution rate increased by $37.8 \%$ in lemma of
Pub under water deficit, whereas a reduction of $12.3 \%$ was observed in Zhe (Fig. 7B).

In middle grouting (from 10 to $20 \mathrm{DAA}$ ), ${ }^{14} \mathrm{C}$-photosynthate rapidly withdrew in lemma (including awns). In late grouting (at $20 \mathrm{DAA}$ ), the distribution rate was constant, suggesting that most of ${ }^{14} \mathrm{C}$-photosynthate had been completely transported. On harvest, the distribution rate increased by $17.0 \%$ in the lemma of Pub under water deficit and decreased by $15.3 \%$ in Zhe. Compared to glume, lemma showed a higher ${ }^{14} \mathrm{C}$-photosynthate retention rate in both varieties (Fig. 7C).

In the middle and late periods of grouting, the 


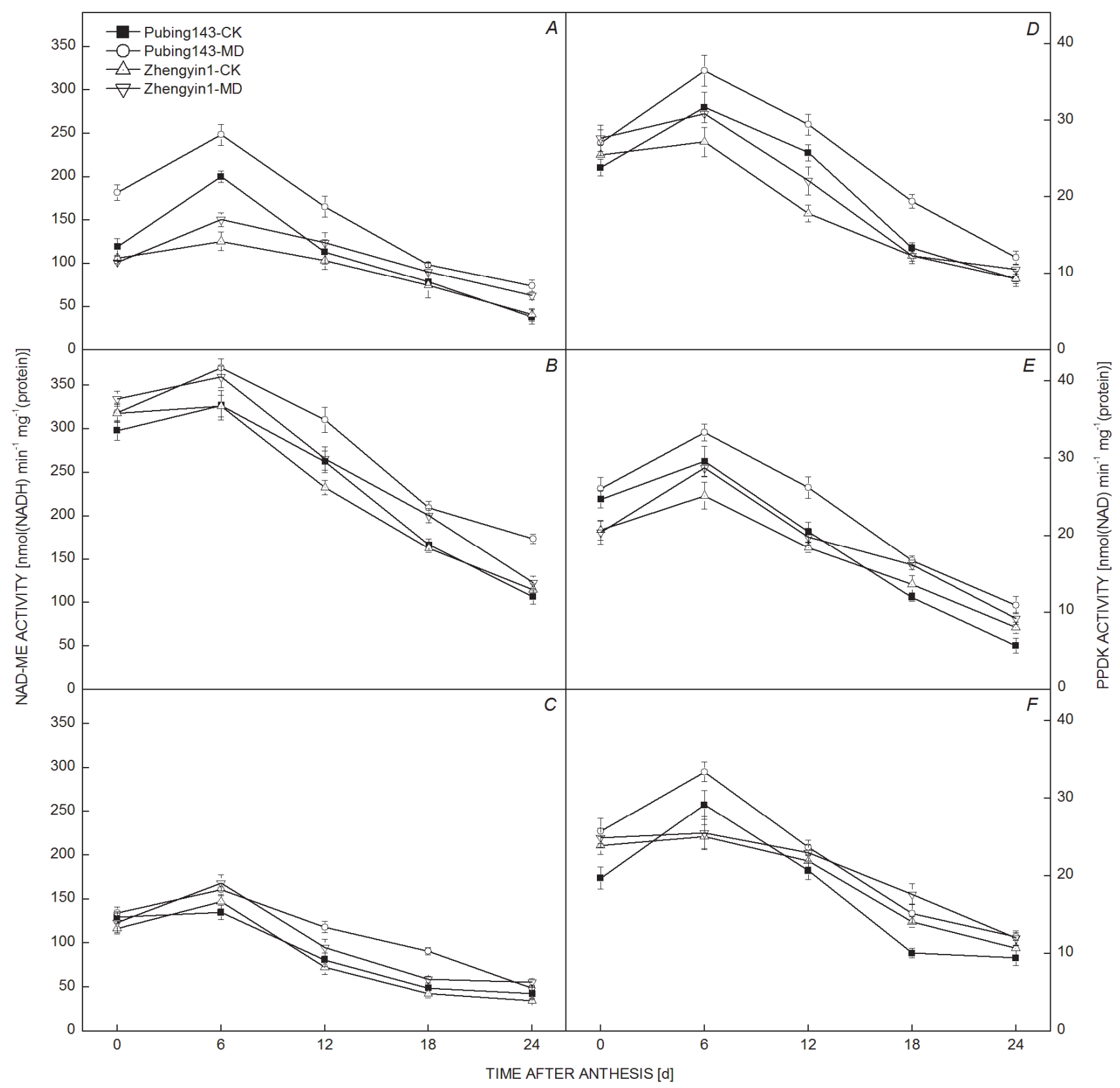

Fig. 6. Effect of water deficit on NAD-malic enzyme (NAD-ME) $(A, B, C)$, pyruvate orthophosphate dikinase (PPDK) $(D, E, F)$ activity in glume $(A, D)$, lemma $(B, E)$, and palea $(C, F)$ of wheat after anthesis (Pubing 143 - drought-resistant cultivar, Zhengyin 1- droughtsensitive cultivar). $\mathrm{CK}$ - control with normal water supply; MD - moderate water deficit.

${ }^{14} \mathrm{C}$-photosynthate distribution rate gradually decreased in palea (Fig. 7D) and rachis (Fig. 7E). A low distribution rate in palea and rachis was observed because of their location inside the ear, thus, receiving less light.

Under water deficit, the carbon assimilate retention rate of spike bracts slightly increased in Pub during the late grouting stage, whereas it significantly dropped in Zhe. Therefore, the effect of water deficit promoted transport of photosynthates in ear bracts to grain in Zhe, and retained little in Pub.
Spike dry matter distribution: After the late grain filling period, the dry matter distribution rate became significantly higher in the grain than that in other ear organs; it was significantly higher in glume and lemma than in palea and rachis. Under water deficit, the distribution rate of dry matter increased in grain of Pub, and declined in spike bracts and rachis, whereas, the distribution rate decreased in grain of Zhe, and increased in bracts and rachis. The distribution rate of dry matter increased in ear bracts and rachis of both varieties under water deficit, with 


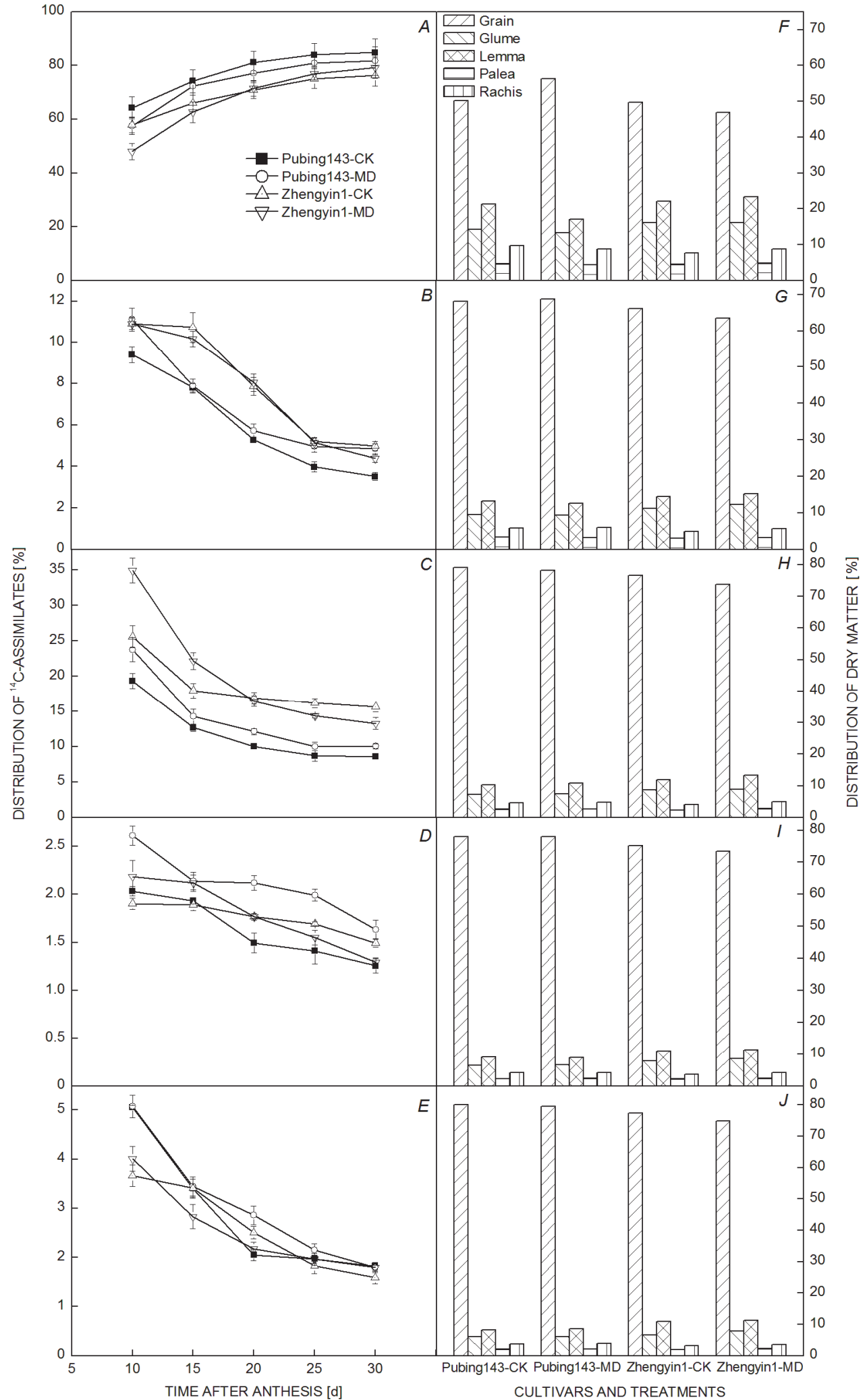

Fig. 7. Effect of water deficit on the distribution of ${ }^{14} \mathrm{C}$-assimilates accumulated during mid-grain filling stage in grain $(A)$, glume $(B)$, lemma $(C)$, palea $(D)$, and rachis $(E)$ of wheat, and the distribution of dry matter in different organs of wheat spike $10 \mathrm{~d}(F), 15 \mathrm{~d}(G), 20$ $\mathrm{d}(H), 25 \mathrm{~d}(I)$ and $30 \mathrm{~d}(J)$ after anthesis (Pubing 143 drought-resistant cultivar, Zhengyin $1-$ droughtsensitive cultivar). CK control with normal water supply; MD - moderate water deficit.
Zhe showing a larger ascent. Thus, variation amplitude was significant for distributing dry matter in spike bracts and rachis of Zhe under drought stress, whereas no significant change was observed in Pub (Fig. $7 F_{-} J$ ).
Wheat yield and WUE: Under water deficit, the number of spikelets did not significantly vary. The number of fertile spikelets significantly decreased by $7.7 \%$ in Zhe. The number of kernels significantly decreased by 15.7 
and $18.6 \%$ in Pub and Zhe, respectively. The mass of grains per ear in Pub and Zhe variety significantly decreased by 22.2 and $29.3 \%$, respectively, and the 1000-kernel mass declined by 11.0 and $13.4 \%$ in Pub and Zhe, respectively. Compared to Zhe, Pub was less influenced by water deficit concerning yield characteristics (Table 1). Biomass per pot did not change significantly, the yield and HI significantly decreased by 25.1 and $17.5 \%$, respectively, in Zhe (Table 1).

Under water deficit, $t_{1}$ was significantly advanced during grain filling in Pub, but it did not obviously change in Zhe. The $\mathrm{t}_{2}$ in Pub moved up by $0.7 \mathrm{~d}$ and $0.5 \mathrm{~d}$

\section{Discussion}

Change in wheat spike photosynthetic characteristics: An important contribution of wheat ear photosynthesis to grain yield was observed. It was apparently more significant under water deficit (Maydup et al. 2010). In this study, spike $P_{\mathrm{N}}$ peaked at $6 \mathrm{DAA}$ (Fig. $2 A$ ), which was consistent with findings of our previous research (Ren et al. 2012, Zhang et al. 2013). The study also showed that ear $P_{\mathrm{N}}$ decreased less in Pub than in Zhe during the grain filling stage under water deficit; Pub spike photosynthesis exhibited minor changes under water deficit (Inoue et al. 2004). Compared to the flag leaf (Fig. $2 B$ ), spike photosynthesis was not sensitive to drought conditions, showing a large contribution to the grain yield (Araus et al. 1993). Chl contents of spike bracts were small (Fig. 3A-C), suggesting the relative stability of ear photosynthetic apparatus and relatively high photochemical efficiency that might help in maintaining ear photosynthesis during the grain filling period in water deficient plants (Martinez et al. 2003). With regard to ear $E$, RWC ranges of glume and lemma were lesser (Fig. 3D,E), indicating that osmotic regulation and photosynthetic components had biological significance in glume and lemma of Pub compared with that of Zhe. Thus, senescence was delayed and adaptation to drought conditions was achieved by maintaining a buffer function. The RWC range was smaller in ear than in flag leaf to maintain high osmotic regulation (Tambussi et al. 2007). The changes in the trend of ear photosynthesis, Chl content and RWC of glume, lemma, and palea were consistent, which suggested that Pub retained relatively high photosynthetic capacity and water retention ability under water deficit. Otherwise, wheat ear photosynthesis might be under stress.

Change in $\mathrm{C}_{4}$ pathway enzyme activity: Although wheat is a $C_{3}$ plant, it possesses also the $C_{4}$ pathway enzymes with large differences in activity in different organs (Singal et al. 1986). In this study, Rubisco activity significantly decreased in different organs under water deficit, showing that the enzyme activity was more sensitive to water stress. $\mathrm{C}_{4}$ pathway enzymes, such as PEPC and NADP-MDH in ear organs, exhibited increasing in Pub and Zhe, respectively The $t_{\max }$ was advanced by $1.9 \mathrm{~d}$ and $2.0 \mathrm{~d}$ in Pub and Zhe, respectively. Changes in $\mathrm{T}$ were not obvious in Pub, whereas in Zhe, they were reduced by $2.9 \mathrm{~d} . \mathrm{V}_{\mathrm{t} 1}$ and $\mathrm{V}_{\mathrm{t} 2}$ exhibited no significant change in both varieties. $\mathrm{V}_{\max }$ slightly rose in Pub, whereas in $Z$ he, it was reduced by $4.2 \%$. A decline was 12.6 and $17.3 \%$ in Pub and Zhe, respectively. Compared to Zhe, Pub showed a smaller effect on maximum grain filling duration under drought and it rose at the maximum grain filling rate. Hence, the grain yield decline became lower, which might be one of the reasons for the drought resistance of Pub (Table 2).

activities under water deficit (Figs. $3 G-I, 4 A-C$ ), especially, in glume and lemma, suggesting that drought conditions could induce the activity of $\mathrm{C}_{4}$ pathway enzymes (Wei et al. 2003). Since only the activity of PEPC seems to parallel with drought tolerance, PEPC enhanced accumulation of the osmolyte proline which can be supplied via aspartic acid. The protection of cells against drought stress by proline enables the maintenance of photosynthetic activity under the water deficit conditions. This might be the reason for the relatively stable photosynthetic rate and the yield of the spike organs under water deficit. In addition, compared to Zhe, $\mathrm{C}_{4}$ pathway enzyme activity increased more significantly in Pub under water deficit, which showed that the $\mathrm{C}_{4}$ pathway enzymes might act in drought tolerance mechanism.

${ }^{14} \mathrm{C}$-photosynthate transport and distribution in spike: The photosynthate of grain is derived from the photosynthetic product before anthesis, and the nonstructural carbohydrates are stored in the leaf sheath and stem. Araus (1993) found that ear photosynthetic products exhibit an obvious increase in the contribution rate to grain under water deficit. In this study, compared with normal water supply, spike bract ${ }^{14} \mathrm{C}$-photosynthate distribution rate decreased by $20.4 \%$ in Zhe under water deficit from 10 to 20 DAA (the key grouting stage), whereas a slight decrease of $7.6 \%$ was observed in Pub (Fig. $7 B-E$ ). From 20 to $30 \mathrm{DAA}$, the distribution of ${ }^{14} \mathrm{C}$-photosynthate (coming from middle grain filling) tended to be stable within the bracts of both varieties, which suggested that spike ${ }^{14} \mathrm{C}$-photosynthate was completely transferred. After harvest, compared with normal water supply, the ${ }^{14} \mathrm{C}$-photosynthate distribution rate significantly dropped in Zhe bracts under water deficit, and grain ${ }^{14} \mathrm{C}$-photosynthate distribution rate significantly increased, whereas in Pub grain, a significant drop was observed. These observations indicate that Zhe increased the transport of ${ }^{14} \mathrm{C}$-photosynthate from bracts to the grain to compensate for the decline of the ear photosynthesis. $\mathrm{C}_{4}$ enzyme activity was high in early grain filling 


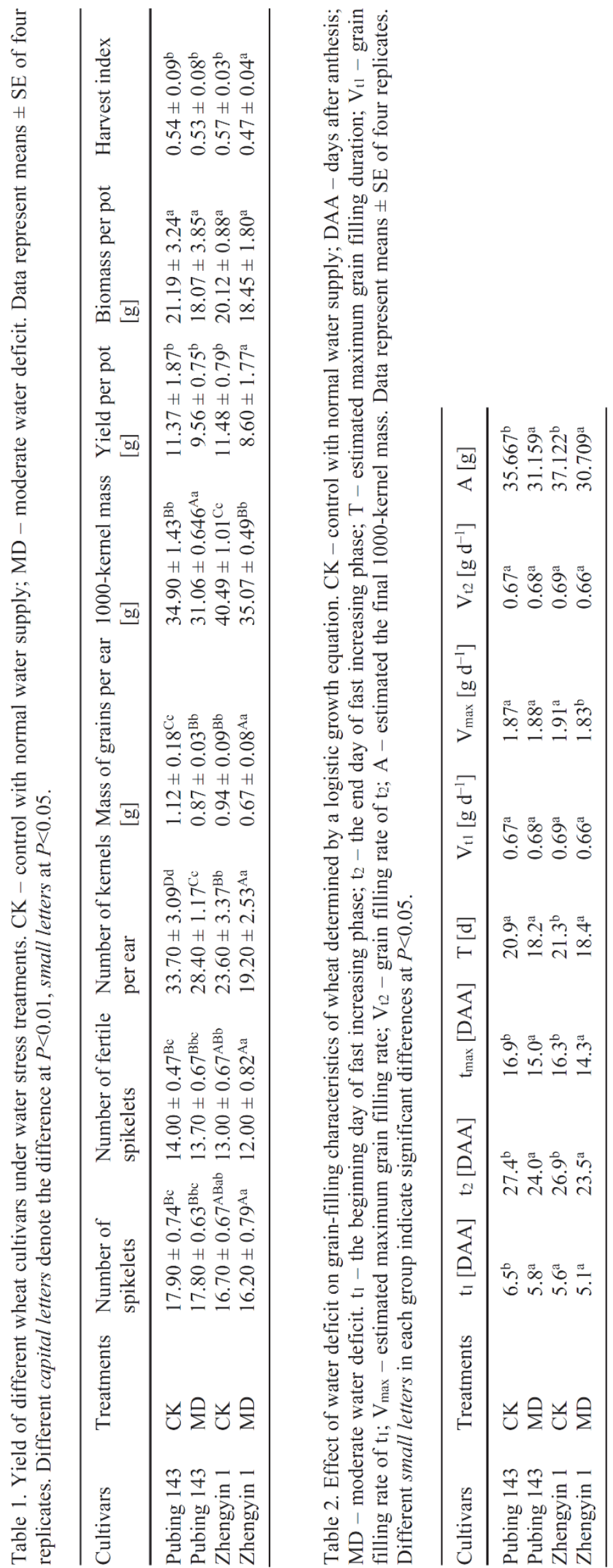


and rapidly dropped in late grain filling, indicating an accumulation of photosynthetic carbon assimilates that mainly occurred in the early grain filling stage. This result was consistent with our previous results $7 \mathrm{~d}$ before and $7 \mathrm{~d}$ after anthesis (Ren et al. 2012, Zhang et al. 2013). Therefore, high photosynthetic efficiency and high $\mathrm{C}_{4}$ pathway enzyme activity are fundamental and it could provide theoretical basis for dry land wheat breeding selection.

Yield and harvest index decline were not apparent in Pub under water deficit (Table 1), whereas that of Zhe dropped by 25.1 and $17.5 \%$, respectively, suggesting that the photosynthate retention rate was lower in spike bracts of Pub, which ultimately increased the grain yield under drought condition. Thus, photosynthetic efficiency, water retention ability, and $\mathrm{C}_{4}$ pathway enzyme activity can provide a fundamental contribution to the yield constant of Pub. This study was limited to differences in ear bract $\mathrm{C}_{4}$ pathway enzyme activity and ${ }^{14} \mathrm{C}$-photosynthate distribution in the grain filling stage, tracing photosynthate transport and disposition after anthesis under water deficit. Awns, despite earning a certain proportion of spike photosynthesis, were not included in this study in consideration of its organ specificity. This should be a subject for further research.

In conclusion, ear photosynthesis and $\mathrm{C}_{4}$ pathway enzymes play important functions in wheat photosynthetic carbon fixation during grain filling, particularly, in Pub cultivar. Ear photosynthesis may be one of the reasons for the high enzyme activity of the $\mathrm{C}_{4}$ pathway and the high photosynthate transport capacity, thus the drought tolerance of ears.

Open Access This article is distributed under the terms of the Creative Commons Attribution License which permits any use, distribution, and reproduction in any medium, provided the original author(s) and the source are credited.

\section{References}

Abebe T., Melmaiee K., Berg V. et al.: Drought response in the spikes of barley: gene expression in the lemma, palea, awn, and seed. - Funct. Integr. Genomics 10: 191-205, 2010.

Aoyagi K., Bassham J.A.: Pyruvate orthophosphate dikinase in wheat leaves. - Plant Physiol. 73: 853-854, 1983.

Aoyagi K., Bassham J.A.: Pyruvate orthophosphate dikinase of $\mathrm{C}_{3}$ seeds and leaves as compared to the enzyme from maize. Plant Physiol. 75: 387-392, 1984a.

Aoyagi K., Bassham J.A.: Pyruvate orthophosphate dikinase mRNA organ specificity in wheat and maize. - Plant Physiol. 76: 278-280, 1984b.

Araus J., Brown H., Febrero A. et al.: Ear photosynthesis, carbon isotope discrimination and the contribution of respiratory $\mathrm{CO}_{2}$ to differences in grain mass in durum wheat. - Plant Cell Environ. 16: 383-392, 1993.

Blanke M.M., Ebert G.: Phosphoenolpyruvate carboxylase and carbon economy of apple seedlings. - J. Exp. Bot. 43: 965-968, 1992.

Bort J., Brown R.H., Araus J.L.: Lack of $\mathrm{C}_{4}$ photosynthetic metabolism in ears of $\mathrm{C}_{3}$ cereals. - Plant Cell Environ. 18: 697-702, 1995.

Bort J., Brown R.H., Araus J.L.: Refixation of respiratory $\mathrm{CO}_{2}$ in the ears of $\mathrm{C}_{3}$ cereals. - J. Exp. Bot. 47: 1567-1575, 1996.

Bort J., Febrero T.A.: Role of awns in ear water-use efficiency and grain mass in barley. - Agronomie 14: 133-139, 1994.

Brownell P., Bielig L., Grof C.: Increased carbonic anhydrase activity in leaves of sodium deficient $\mathrm{C}_{4}$ plants. - Aust. J. Plant Physiol. 18: 589-592, 1991.

Camp P.J., Huber S.C., Burke J.J. et al.: Biochemical changes that occur during senescence of wheat leaves: I. Basis for the reduction of photosynthesis. - Plant Physiol. 70: 1641-1646, 1982.

Comstedt D., Boström B., Marshall J.D. et al.: Effects of elevated atmospheric carbon dioxide and temperature on soil respiration in a boreal forest using $\delta^{13} \mathrm{C}$ as a labelling tool. Ecosystems 9: 1266-1277, 2007.

Davood E.A., Alireza H.: Rubisco and PEP-carboxylase levels in relation to grain development within a spikelet of wheat. Adv. Environ. Biol. 5: 1746-1750, 2011.
Ekblad A., Högberg P.: Analysis of $\delta^{13} \mathrm{C}$ of $\mathrm{CO}_{2}$ distinguishes between microbial respiration of added $\mathrm{C}_{4}$-sucrose and other soil respiration in a $\mathrm{C}_{3}$-ecosystem. - Plant Soil 219: 197-209, 2000.

Gajewska E., Niewiadomska E., Tokarz K. et al.: Nickelinduced changes in carbon metabolism in wheat shoots. J. Plant Physiol. 170: 369-377, 2013.

González M.C., Echevarría C., Vidal J. et al.: Isolation and characterisation of a wheat phosphoenolpyruvate carboxylase gene. Modelling of the encoded protein. - Plant Sci. 162: 233-238, 2002

González M.C., Osuna L., Echevarría C. et al.: Expression and localization of phosphoenolpyruvate carboxylase in developing and germinating wheat grains. - Plant Physiol. 116: 1249-1258, 1998.

González M.C., Sanchez-Bragado R., Cejudo F.J.: Abiotic stresses affecting water balance induce phosphoenolpyruvate carboxylase expression in roots of wheat seedlings. - Planta 216: 985-992, 2003

Hu W., Huang C., Deng X. et al.: TaASR1, a transcription factor gene in wheat, confers drought stress tolerance in transgenic tobacco. - Plant Cell Environ. 8: 1449-1464, 2013.

Inoue T., Inanaga S., Sugimoto Y. et al.: Effect of drought on ear and flag leaf photosynthesis of two wheat cultivars differing in drought resistance. - Photosynthetica 42: 559-565, 2004.

Kong L., Wang F., Feng B. et al.: The structural and photosynthetic characteristics of the exposed peduncle of wheat (Triticum aestivum L.): an important photosynthate source for grain-filling. - BMC Plant Biol. 10: 1-10, 2010.

Kuzyakov Y., Domanski G.: Model for rhizodeposition and $\mathrm{CO}_{2}$ efflux from planted soil and its validation by ${ }^{14} \mathrm{C}$ pulse labelling of ryegrass. - Plant Soil 239: 87-102, 2002.

Li H., Cai J., Jiang D. et al.: Carbohydrates accumulation and remobilization in wheat plants as influenced by combined waterlogging and shading stress during grain filling. J. Agron. Crop Sci. 199: 38-48, 2013.

Li X., Hou J., Bai K. et al.: Activity and distribution of carbonic anhydrase in leaf and ear parts of wheat (Triticum aestivum 
L.). - Plant Sci. 166: 627-632, 2004.

Martinez D.E., Luquez V.M., Bartoli C.G. et al.: Persistence of photosynthetic components and photochemical efficiency in ears of water-stressed wheat (Triticum aestivum). - Physiol. Plantarum 119: 519-525, 2003.

Matsuhashi S., Fujimaki S., Uchida H. et al.: A new visualization technique for the study of the accumulation of photoassimilates in wheat grains using ${ }^{11} \mathrm{CO}_{2}$. - Appl. Radiat. Isotopes 64: 435-440, 2006.

Matsuoka M. Hata S.: Comparative studies of phosphoenolpyruvate carboxylase from $\mathrm{C}_{3}$ and $\mathrm{C}_{4}$ plants. - Plant Physiol. 85: 947-951, 1987.

Maydup M.L., Antonietta M., Guiamet J.J. et al.: The contribution of ear photosynthesis to grain filling in bread wheat (Triticum aestivum L.). - Field Crop. Res. 119: 48-58, 2010.

Maydup M.L., Antonietta M., Guiamet J.J. et al:: The contribution of green parts of the ear to grain filling in old and modern cultivars of bread wheat (Triticum aestivum L.): Evidence for genetic gains over the past century. - Field Crop Res. 134: 208-215, 2012.

Moroney J.V., Husic H.D., Tolbert N.E.: Effect of carbonic anhydrase inhibitors on inorganic carbon accumulation by Chlamydomonas reinhardtii. - Plant Physiol. 79: 177-183, 1985.

Nagy Z., Guóth A., Németh E. et al.: Metabolic indicators of drought stress tolerance in wheat: Glutamine synthetase isoenzymes and Rubisco. - Plant Physiol. Biochem. 67: 48-54, 2013.

Nguyen C., Todorovic C., Robin C. et al.: Continuous monitoring of rhizosphere respiration after labelling of plant shoots with ${ }^{14} \mathrm{CO}_{2}$. - Plant Soil 212: 189-199, 1999.

Ostle N., Ineson P., Benham D. et al.: Carbon assimilation and turnover in grassland vegetation using an in $\operatorname{situ}{ }^{13} \mathrm{CO}_{2}$ pulse labelling system. - Rapid Commun. Mass Sp. 14: 1345-1350, 2000.

Osuna L., González M.C., Cejudo F.J. et al.: In vivo and in vitro phosphorylation of the phosphoenolpyruvate carboxylase from wheat seeds during germination. - Plant Physiol. 111: 551-558, 1996.

Pang J., Palta J.A., Rebetzke G.J., Milroy S.P.: Wheat genotypes with high early vigour accumulate more nitrogen and have higher photosynthetic nitrogen use efficiency during early growth. - Funct. Plant Biol, 41:215-222, 2013.

Ren Y.T., Lv J.Y., Cheng J.: [Effects of water deficit on photosynthetic characteristics, accumulation and transportation of ${ }^{14} \mathrm{C}$-assimilates of ears in wheat.] - J. Triticeae Crops 32: 683-688, 2012. [In Chinese]

Sanchez-Bragado R., Elazab A., Zhou B. et al.: Contribution of the ear and the flag leaf to grain filling in durum wheat inferred from the carbon isotope signature: genotypic and growing conditions effects. - J. Integr. Plant Biol. 56: 444-454, 2014.

Sánchez-Díaz M., García J., Antolín M. et al.: Effects of soil drought and atmospheric humidity on yield, gas exchange, and stable carbon isotope composition of barley. Photosynthetica 40: 415-421, 2002.

Sayre R.T, Kennedy R.A., Pringnitz D.J.: Photosynthetic enzyme activities and localization in Mollugo verticillata populations differing in the levels of $\mathrm{C}_{3}$ and $\mathrm{C}_{4}$ cycle operation. - Plant Physiol. 64: 293-299, 1979.

Schwender J., Goffman F., Ohlrogge J.B. et al: Rubisco without the Calvin cycle improves the carbon efficiency of developing green seeds. - Nature 432: 779-782, 2004.

Singal H.B., Sheoran I.S., Singh R.: In vitro enzyme activities and products of ${ }^{14} \mathrm{CO}_{2}$ assimilation in flag leaf and ear parts of wheat (Triticum aestivum L.). - Photosynth. Res. 8: 113-122, 1986.

Steinmeyer F.T., Martin L., Matthew P. R. et al.: Quantifying the relationship between temperature regulation in the ear and floret development stage in wheat (Triticum aestivum L.) under heat and drought stress - Funct. Plant Biol. 40: 700-707, 2013.

Tambussi E.A., Bort J., Guiamet J.J. et al.: The photosynthetic role of ears in $\mathrm{C}_{3}$ cereals: Metabolism, water use efficiency and contribution to grain yield. - Crit. Rev. Plant Sci. 26: 1-16, 2007.

Teare I.D., Peterson C.J.: Surface area of chlorophyll-containing tissue on the inflorescence of Triticum aestivum L. - Crop Sci. 11: 627-628, 1971.

Thornton B., Paterson E., Midwood A.J. et al.: Contribution of current carbon assimilation in supplying root exudates of Lolium perenne measured using steady-state ${ }^{13} \mathrm{C}$ labelling. Physiol. Plantarum 120: 434-441, 2004.

Tsuzuki M., Miyachi S., Edwards G.E.: Localization of carbonic anhydrase in mesophyll cells ofterrestrial $\mathrm{C}_{3}$ plants in relation to $\mathrm{CO}_{2}$ assimilation. - Plant Cell Physiol. 26: 881891, 1985.

Wang Z.M., Zhang Y.H., Zhang Y.P. et al.: [Review on photosynthetic performance of ear organs in Triticeae crops.] - J. Triticeae Crops 24: 136-139, 2004. [In Chinese]

Wei A.L., Wang Z.M., Zhai Z.X. et al.: [Effect of soil drought on $\mathrm{C}_{4}$ photosynthetic enzyme activities of flag leaf and ear in wheat.] - Sci. Agric. Sin. 36: 508-512, 2003. [In Chinese]

Xue Q., Zhu Z., Musick J.T. et al.: Physiological mechanisms contributing to the increased water-use efficiency in winter wheat under deficit irrigation. - J. Plant Physiol. 163: 154-164, 2006

Zhang Y.H., Zhou S.L., Huang Q. et al.: Effects of sucrose and ammonium nitrate on phosphoenolpyruvate carboxylase and ribulose-1,5-bisphosphate carboxylase activities in wheat ears. - Aust. J. Crop Sci. 6: 822-827, 2012.

Zhang L., Lv J.Y., Jia S.L.: [Photosynthetic characteristics of spike and distribution of ${ }^{14} \mathrm{C}$-assimilates accumulated before anthesis in wheat under water deficit condition.] - Acta Agron. Sin. 39: 1514-1519, 2013. [In Chinese]

Zhang Y.H., Su D., Zhang S.Q. et al.: [Phosphoenolpyruvate carboxylase activity of flag leaf and ear organs and its relationship with grain mass and protein content in winter wheat under different water treatments.] - J. Triticeae Crops 29: 997-1003, 2009. [In Chinese]

Zhang Y.P., Wang Z.M., Wang P. et al.: [Canopy photosynthetic characteristics of population of winter wheat in water-saving and high-yielding cultivation.]-Sci. Agric. Sin. 36: 1143-1149, 2003. [In Chinese]

Zhang Y.P., Zhang Y.H., Wang Z.M.: [Photosynthetic diurnal variation characteristics of leaf and non-leaf organs in winter wheat under different irrigation regimes.] - Acta Ecol. Sin. 31 1312-1322, 2011. [In Chinese] 